\title{
Tourism trails as tools for cross-border integration: A best practice case study of the Vennbahn cycling route
}

\author{
Arie Stoffelen \\ Department of Cultural Geography, Faculty of Spatial Sciences, University of Groningen, Landleven 1, 9746AD Groningen, Netherlands
}

\section{A R T I C L E I N F O}

Associate editor: Bill Bramwell

Keywords:

Cycling routes

Cycling trails

Cross-border cooperation

Regional development

Borderlands

Institutional asymmetry

\begin{abstract}
A B S T R A C T
This paper evaluates which processes determine the leverage of cycling tourism trails for mainstreaming cross-border contact and 'soft' region-building. Reflecting on the Vennbahn between Germany, Belgium and Luxemburg, the paper shows that the influence of routes on crossborder integration depends on the trail's strength as a tourism product, its cross-border institutionalization, and the geography and scale of the trail and the involved destinations. Tourism trails could contribute to cross-border integration, vindicating the substantial money spent on such projects in INTERREG programmes. However, border-related barriers remain robust even for tourism projects that are best practices of cross-border cooperation. As such, there is an unfulfilled potential of tourism trails in their contribution to cross-border communication and social cohesion in many European borderlands.
\end{abstract}

\section{Introduction}

Hiking and cycling trails have become significant tourism phenomena throughout Europe. Routes and trails have been developed on different scales and include itineraries with vastly different lengths and themes (MacLeod, 2017; Timothy \& Boyd, 2015). In Europe, they range from numerous individual projects in mostly rural and nature-based destinations to extra-regional networks such as the RAVeL cycling route network in Wallonia (Belgium) or the National Cycle Network in the UK. Also on a pan-European level, cycling trails have become tools for European region-building, regional marketing and increasing the awareness for sustainable transport transitions (Lumsdon, 2000; Stoffelen \& Vanneste, 2018a). For example, the EuroVelo network, coordinated by the European Cyclists' Federation (ECF), combines these aims in a platform that currently incorporates 15 long-distance routes with a total length of $45.000 \mathrm{~km}$ (ECF, 2017).

Hiking and cycling routes and trails have also become prominent tourism products in cross-border contexts (Timothy \& Boyd, 2015; Timothy, Saarinen, Viken, \& Tourism, 2016). The noted advantages of developing tourism trails across administrative borders are numerous. Tourism in general is regularly noted as one of the 'easier' ways of establishing cross-border contact (Church \& Reid, 1999; Deppisch, 2012). Additionally, tourism trails could utilize existing infrastructure and abandoned railway tracks for route development, join local stakeholders in a shared cross-border project and lead to increased cross-border mobility of not only tourists but also locals (Stoffelen \& Vanneste, 2017; Timothy \& Boyd, 2015; Timothy et al., 2016). Following these assumed synergetic impacts that move beyond benefitting just the tourism industry, hiking and cycling routes receive a strikingly high share of the funds spent on tourism in the INTERREG co-financing scheme. A calculation using the lists of beneficiaries of 53 out of 55 INTERREG IV-a programmes throughout Europe shows that themed trails and hiking and cycling routes combined received more than $35 \%$ of the funds spent on tourism between 2007 and 2013, totalling roughly 370 million Euros.

E-mail address: h.j.w.stoffelen@rug.nl. 
However, the processes through which tourism routes and trails could leverage cross-border integration, which is defined in this paper as mainstreaming cross-border contact, facilitating economic development and 'soft' region-building, are highly complex. 'Soft' region-building refers to the symbolic breaking down of administrative obstacles, dissolving of mental borders and facilitating of shared mindsets. Qualitative studies on the functioning of such projects could highlight these processes in more detail than INTERREG's own predominantly quantitative output and results indicators (Vanclay, 2015). Despite often positive assumptions that benefits could be achieved with tourism trails (Hayes \& Macleod, 2008), previous research has shown that cross-border tourism routes may not necessarily have the desired effects. For example, Stoffelen, Ioannides \& Vanneste (2017) observed for the GermanCzech borderlands that many cross-border cycling trails have been developed, most of them co-financed by the INTERREG IV-a program. However, lacking coordination between the projects and stakeholders has resulted in their dubious longevity, an uncertain tourism potential and no strategic vision on how to combine these local efforts to reach benefits for the whole cross-border region, despite potentially positive quantitative indicators.

Hence, Timothy et al. (2016) call for more systematic research on cross-border tourism trails in European contexts to better understand the management requirements of these tourism products. Following this call, this paper adopts a middle range research approach with an explorative, in-depth qualitative case study of one of the more successful European cross-border cycling routes to deepen our practical understanding as well as conceptual thinking on the processes through which route tourism could leverage cross-border integration. The Vennbahn, a 125-kilometre-long cycling trail across the borders of Germany, Belgium and Luxemburg, is one of the most prominent cross-border tourism products in Europe in terms of international marketing exposure. It has also been labelled by the Euroregion Meuse-Rhine (EMR) as a symbolic highlight for the transnational cooperation in the area (Stoffelen \& Vanneste, 2017). It seems, from these views, that the Vennbahn is a best practice, both in establishing a successful cross-border tourism route and in using this route to reach cross-border cooperation aims. Therefore, through this best practice case study, the paper considers the following research question:

Which processes explain the success, or lack thereof, of the leverage of cross-border cycling routes for cross-border integration?

To answer this question, the paper positions itself at the interface of the literatures on tourism routes and cross-border tourism cooperation. While the former body of literature is predominantly based on case study evidence, the latter is more informed by conceptual models on the openness of borders, cross-border interaction types and the attractiveness of borderlands (e.g. Martínez, 1994; Timothy, 1995, 1999) as well as case studies that follow these perspectives. In general, cross-border tourism studies build on what Van Houtum (2000) describes as the 'cross-border cooperation approach' to border studies, which sees regional and partnership-based cross-border cooperation as a way to economically and socio-culturally benefit borderlands. This approach fits within the institutional turn in geography that highlights the role of institutions, both emplaced socio-cultural conventions and the administrative organization, to achieve development (Amin \& Thrift, 1994). Hence, systematically reviewing and building bridges between these literatures allows to increase our conceptual thinking as well as provide an explorative frame to create a more nuanced understanding of the practical processes through which tourism routes could leverage cross-border integration.

\section{Literature review}

Regional leverage of tourism trails

Tourism routes, especially themed trails on food and beverages and cultural heritage, have been under scrutiny from several research perspectives. On the one hand, a research field exists that focuses on tourism product development, trail stakeholder management and visitors' experiences (e.g. MacLeod, 2017; Mason \& O'Mahony, 2007; Quinlan Cutler, Carmichael, \& Doherty, 2014). On the other hand, a more development-oriented group of studies examines the contribution of tourism routes to rural destinations (e.g. Briedenhann \& Wickens, 2004; Rogerson, 2007; Snowball \& Courtney, 2010). This research generally highlights the potential of routes to diffuse tourism-related impacts to peripheral areas, shape the economic footprint of tourists to form a consumption path along the trail itinerary and connect local stakeholders in destination networks (Meschik, 2012; Meyer, 2004; Rogerson, 2007; Timothy \& Boyd, 2015). Regarding cycling tourism, the rather long lengths of stay, the ability to disperse tourists from hotspots into the surrounding countryside, the use of existing infrastructure and the potential to build towards sustainable tourism transport systems add to route tourism's development capacity (Lumsdon, 2000; Ritchie \& Hall, 1999).

Summarizing the literature to uncover pro-poor effects with tourism trails, Meyer (2004, pp. 14-15) identifies five "key ingredients for successful route developments". These are (i) cooperation networks, regional thinking and leadership; (ii) product development, infrastructure and access; (iii) community participation, micro-enterprise development and innovation; (iv) information and promotion; and (v) an explicit pro-poor focus. These findings imply that tourism routes should be successful tourism products and be able to transform this success into regional synergy effects. As is the bottom line for all tourism products, a trail's leverage for reaching local or regional benefits is undermined without long-term stability and attractiveness of the tourism product. Yet, attractive tourism routes are not necessarily successful in terms of broader development effects. There is a consensus that a stable financial organization and a strategic long-term vision in the management of tourism trails is at the basis of making this connection (Taylor, 2015; Timothy \& Boyd, 2015). For example, Plummer, Telfer, and Hashimoto (2006) show for the Waterloo-Wellington Ale Trail in Canada that competition among members, unclear goals of the partnership and internal disagreement ultimately brought down the trail that provided an otherwise successful tourism product.

Cooperative planning should allow for both managerial stability and the social and spatial dispersal of the trail's impact among stakeholders and in neighbouring areas. Regarding the Malt Whisky Trail in Scotland, previous research has indicated that the closed 
character of the route's network and branding was neither conducive for product innovation nor allowed to bring in the surrounding communities in the decision-making (Martin \& McBoyle, 2006; Stoffelen \& Vanneste, 2016). The strict spatial and organizational boundaries hampered the interlinking of the Malt Whisky Trail with supplementary economic activities and secondary tourism products that could build on the trail's brand strength to attract tourists to areas along and just outside the itinerary of the route (Stoffelen \& Vanneste, 2016). Hence, a 'flat organizational style' that crosses organizational and geographical boundaries and makes connections between sectors and stakeholders is noted to be more in line with regional development philosophies than closed, topdown trail management (Snowball \& Courtney, 2010; Taylor, 2015). Tourism routes with an open and inclusive decision-making network may stimulate cooperation and establish linkages between local communities, the tourism system and wider economic development (Briedenhann \& Wickens, 2004; Meyer, 2004). Tourism trails, therefore, should not only have an 'internal' decisionmaking that allows for community participation and the linking up of supplementary tourism products. They should also safeguard their 'external' incorporation and institutional embeddedness in larger regional, also non-tourism plans (Ryan, Fábos, \& Allan, 2006; Snowball \& Courtney, 2010).

In summary, for hiking and cycling routes to reach their regional leverage effect, the literature review indicates that they should: (i) function as long-term, stable and attractive tourism products; (ii) have a stable financial organization and a strategic long-term vision that moves beyond mere product development; (iii) have a social and spatial dispersal of tourists and impacts; (iv) be supported by an open and inclusive decision-making network; (v) be institutionally embedded in the broader organization of a region.

\section{Complexities for tourism development in borderlands}

In general, cross-border projects aim to overcome development barriers by creating mutual understanding and familiarity among communities and organizations in borderlands (Spierings \& van der Velde, 2013). Since tourism is often seen as a key sector to bring people together across borders (Timothy, 2001), many cross-border tourism projects have been developed in Europe in recent decades, often with co-financing from EU support schemes such as INTERREG. These projects build on an implied demand for borderrelated tourism products. Borderlines themselves can directly function as the object of attention by tourists or indirectly due to contrasting national legislatures and a geographically peripheral location that resulted in unique natural and cultural features (Gelbman \& Timothy, 2010; Timothy, 1995).

The cross-border cooperation model of Martínez (1994), updated by Timothy (1999), has been particularly influential to assess the role of tourism in the opening of borders. These authors classify borderlands according to the intensity of cross-border interaction and the mobility of people. On a scale from practically absent daily contact to almost complete barrier-free flow of people and goods, borderlands can be alienated, coexistent, cooperative, collaborative or integrated. However, the relation between border type and tourism development possibilities is more complex than this linear increase of cooperation intensity. Open and collaborative borders provide welcoming environments for travellers as well as conducive situations to align tourism policies (Sofield, 2006; Stoffelen et al., 2017). Yet, contrast and unfamiliarity also appeal to the imagination of tourists and provide incentives for policymakers to intensify cooperation (Klatt \& Herrmann, 2011; Spierings \& van der Velde, 2013). Therefore, instead of attempting to achieve assimilation it is the search for complementarity, both in tourism products and in economic, social and political institutions, that could lead to more integrative borderlands through tourism development (Timothy, 2001).

Combining anecdotal evidence from case studies, the picture emerges that cross-border tourism projects may be successful in spurring tourism mobility and creating powerful symbols when some form of complementarity is achieved (Gelbman \& Timothy, 2010; Prokkola, 2010). Especially the low political sensitivity to develop tourism compared to other sectors makes tourism projects particularly useful to initiate cross-border contact. Practitioners regularly interpret cross-border tourism projects as relatively easy to establish (Church \& Reid, 1999) or 'conflict free' (Deppisch, 2012). The symbolic and administrative bridging role rather than the direct economic effect of the tourism projects in cross-border cooperation could facilitate shared mindsets and make tourism a 'soft' tool for breaking down administrative borders and mental cooperation barriers (Stoffelen \& Vanneste, 2018b).

However, the search for complementarity in tourism products and in economic, social and political institutions also encounters border-related challenges which directly influence the processes for successful trail development identified from the route tourism literature. For example, Ioannides, Nielsen, and Billing (2006) identified the bureaucratic nature of cross-border tourism projects and the struggle to bring entrepreneurs on board in the Swedish-Finnish borderlands. Additionally, pooling resources and knowledge across borders to not only develop route infrastructure but to also safeguard its longevity requires establishing a stable financial regime that builds on continuous information exchange, which are two processes that remain challenging for tourism routes and in borderlands settings (Morrow, 2005; Saxena \& Ilbery, 2008; Timothy \& Boyd, 2015). Prokkola (2008) found that cross-border tourism projects between Sweden and Finland could be initiated by EU co-funding but the short-term character of this funding undermined the viability of many projects. Moreover, the assumption that borderland settings spur an implicit demand can be challenged in some cases. For the Iron Curtain Trail, a long-distance cycling route that follows the relic Iron Curtain throughout Europe, German stakeholders doubted if the tourism product is strong enough to attract tourists on a daily basis despite the obvious symbolic and educational value of the brand. Also the dependency on other stakeholders along the route and the limited returns that could be gained due to the short length of stay of tourists along the part of the route that runs through their destination were seen as undermining the trail's strength (Stoffelen \& Vanneste, 2018a).

Next to these product development challenges, borderland contexts have also been noted to lead to fundamental complications for systematic governance, inclusive decision-making and institutional embeddedness of tourism (Blasco, Guia, \& Prats, 2014). Several tourism researchers have independently confirmed the consensus in planning studies that cross-border cooperation remains embedded in nationally organized decision-making systems (Blasco et al., 2014; Ioannides et al., 2006; Timothy, 1999). For instance, 
SPATIAL, POLITICAL AND HISTORICAL CONTEXT

\begin{tabular}{|c|c|c|c|c|}
\hline \multicolumn{5}{|c|}{ Cross-border cycling tourism trails } \\
\hline$\downarrow$ & $\downarrow$ & $\downarrow$ & $\downarrow$ & $\downarrow$ \\
\hline $\begin{array}{l}\text { rm stability } \\
\text { activeness } \\
\text { pre as a } \\
\text { product }\end{array}$ & $\begin{array}{l}\text { Stable financial } \\
\text { organization and } \\
\text { a strategic long- } \\
\text { term vision }\end{array}$ & $\begin{array}{l}\text { Social and } \\
\text { spatial dispersal } \\
\text { of tourists and } \\
\text { impacts }\end{array}$ & $\begin{array}{l}\text { Open and } \\
\text { inclusive } \\
\text { decision- } \\
\text { making } \\
\text { network }\end{array}$ & $\begin{array}{l}\text { Institutional } \\
\text { embedded- } \\
\text { ness of the } \\
\text { route }\end{array}$ \\
\hline
\end{tabular}

\section{Preconditions in borderland settings}

\begin{tabular}{|c|c|c|c|c|c|}
\hline $\begin{array}{l}\text { Demand } \\
\text { for border- } \\
\text { celated } \\
\text { tourism } \\
\text { products }\end{array}$ & $\begin{array}{l}\text { Complementarity } \\
\text { on both sides of } \\
\text { the border }\end{array}$ & $\begin{array}{l}\text { Shared mindsets } \\
\text { on cross-border } \\
\text { administrative } \\
\text { and symbolic } \\
\text { bridging role of } \\
\text { the trail }\end{array}$ & $\begin{array}{l}\text { Pooling } \\
\text { resources and } \\
\text { knowledge } \\
\text { for durable } \\
\text { management } \\
\text { structures }\end{array}$ & $\begin{array}{l}\text { Equal linking } \\
\text { up in existing } \\
\text { tourism and } \\
\text { regional } \\
\text { development } \\
\text { plans }\end{array}$ & $\begin{array}{l}\text { Bridging } \\
\text { actors } / \\
\text { legitimate } \\
\text { conveners }\end{array}$ \\
\hline
\end{tabular}

to avoid/overcome,

Institutional asymmetry, bureaucracy, across the border: competition, short-term solutions, dependency on external funds, spatial imbalances, unequal community participation

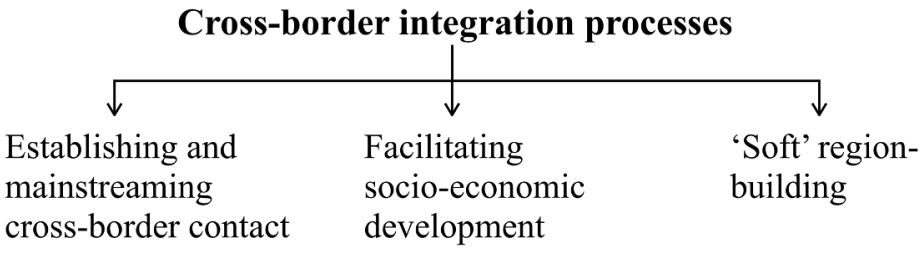

Fig. 1. Explorative framework for studying the leverage of cross-border cycling routes.

Ilbery and Saxena (2011) found for the English-Welsh borderlands that the official view of regional tourist boards emphasizes crossborder cooperation and participation, yet the 'strategic roadmaps' of the regeneration partnerships in the researched counties (two in England, one in Wales) incorporate local initiatives in national rather than cross-border plans. Also for route tourism, research has shown that different countries plan, fund and implement tourism trails in different ways, even in neighbouring countries with similar governmental planning traditions (Antonson \& Jacobsen, 2014). Borders could form the meeting point "of fundamentally different ways of operationalization of tourism governance" and decision-making (Stoffelen et al., 2017, p. 137). This so-called 'institutional asymmetry' in which the multi-level decision-making process on both sides is incompatible across the border, has been noted as a key obstacle to establishing a systematic coordination of cross-border tourism projects (Stoffelen et al., 2017). Such institutional situations, where cross-border actions are not equally linked up in existing tourism and regional development plans on both sides of the border, could consolidate competition rather than lead to complementarity across the border (Ioannides et al., 2006). Bridging actors or legitimate conveners need to be in place to make such dichotomous border situations in tourism work (Blasco et al., 2014; van der Zee, Gerrets, \& Vanneste, 2017).

Fig. 1 synthesizes the attention points from the route tourism literature and the borderland complexities identified from the crossborder tourism literature. As explained below, the conceptual model functions as an explorative lens for the Vennbahn study.

\section{Study area and methodology}

The Vennbahn is a cycling route on abandoned railway tracks, a so-called 'rail trail', between Aachen (Germany) and Troisvièrges 


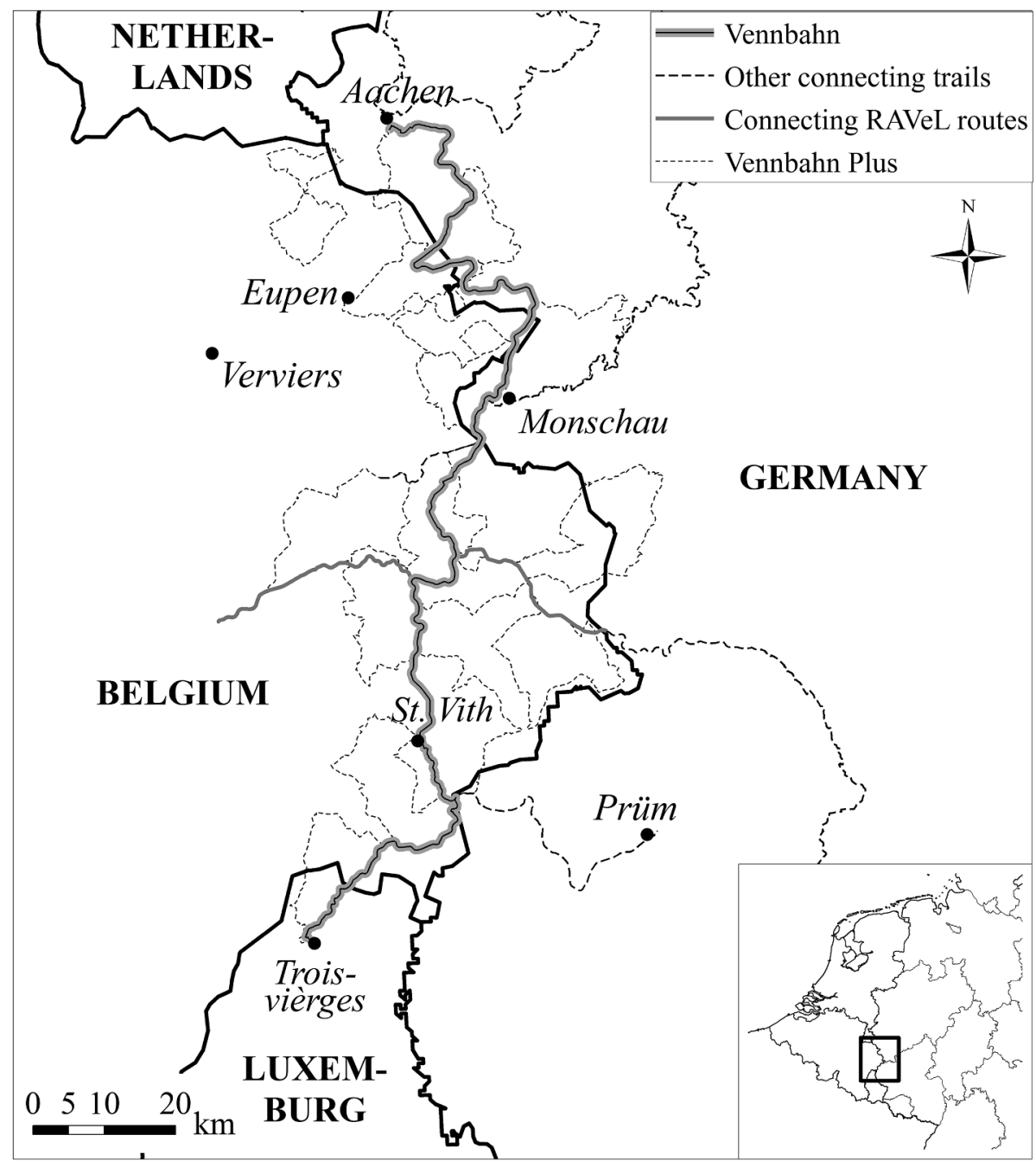

Fig. 2. The Vennbahn and connecting cycling trails.

(Luxemburg) (Fig. 2). The railway was developed in the 19th century for iron ore and coal transport. The economic activity along this line declined after the Second World War. Freight operations terminated in the 1980s (Vennbahn, 2017). After an attempt to create a train-based tourist attraction, the transformation of the Vennbahn to a cycling trail was inspired in the 2000s by the RAVeL network of cycle routes along towpaths and old railways in Wallonia. The project was initiated by the minister of tourism of the Germanspeaking Community of Belgium. Together with the East Belgium tourism association (TAO), which is the destination management organization (DMO) in the German-speaking Community of Belgium, a German partner was found in the director of the Aachen regional district. The German DMO in the area (Eifel Tourismus, ET) joined to develop the project. The trail is operational since 2013 and has become an official RAVeL route. The Vennbahn focuses on recreational use at a leisurely pace to attract young families and senior citizens rather than sports-oriented cyclists (Ministerium der Deutschsprachigen Gemeinschaft, n.d.).

Currently, local practitioners regard the Vennbahn as a strong symbol for what can be achieved with cross-border cooperation (Stoffelen \& Vanneste, 2017). The apparent success of the Vennbahn provides an interesting backdrop to evaluate the processes that determine the cross-border integration potential of tourism routes. A qualitative research design was chosen considering the study's objective to deepen our currently limited practical understanding as well as conceptual thinking on the leverage of tourism routes for cross-border integration. Following institutional perspectives to regional development and cross-border integration, which underpin the cross-border cooperation approach to border studies (Van Houtum, 2000), the study focused on the organization and embedding of the trail in the tourism systems on both sides of the border. As such, 14 semi-structured in-depth interviews were conducted in December 2015 and January 2016 with policymakers, community development organizations and public-private regional development associations. One additional confirmatory interview was conducted in December 2017 to substantiate the findings and add details that, after the data analysis, proved to be missing from the original interviews. Luxembourgian stakeholders were not approached considering their peripheral position in the project, their non-involvement in the EMR which co-financed the route's development, as well as the absence of suitable partners as noted by German and Belgian interviewees (see below). 
After member-checking, the thematic analysis of the interview transcripts centred on an iterative coding process using $\mathrm{NVivo}^{\mathrm{TM}}$. The order of the data analysis steps reflects the middle range thinking that underpins the research. Operating within the existing paradigms of cross-border cooperation and institutional perspectives to development, the data analysis departed from empirical observations. The empirical insights were established independently and only later compared to the current body of knowledge as schematized in Fig. 1. The goal of this comparison was to use the empirical findings to nuance and deepen the content of the explorative framework. Translated into the coding practice, the data analysis consisted, consecutively, of descriptive coding, pattern coding, provisional coding and hierarchical coding. As explained by Stoffelen (2018), topics were first noted as emerging from the interview transcripts (descriptive coding), then restructured to identify overarching topics (pattern coding). These were subsequently systematically compared to the above described literature study through the creation of a predefined set of nodes (provisional coding). Comparison of the pattern and provisional coding schemes led to an aggregated hierarchical coding scheme, which provides a middle way between the 'bottom-up' empirical content and the elements from the explorative framework that followed from the literature review. After the hierarchical coding of the interview transcripts, a descriptive analytical document was created with short summaries for each node in the hierarchical coding scheme. The resulting document was used to identify the main research findings.

Following the systematic comparison of empirical observations with the literature study, the results section is organized according to the processes identified from the route tourism literature as summarized in Fig. 1. This structure is used to describe the emerged empirical findings on lower hierarchical levels in the final coding scheme in the light of the complexities of cross-border settings schematized in the literature synthesis (Fig. 1). By doing so, the paper uses empirically grounded insights to deepen and nuance the explorative framework.

\section{Results}

Long-term stability and attractiveness of the route as a tourism product

While the Vennbahn is a relatively recent addition to the tourism landscape of East Belgium and the German Eifel with its inception in 2013, the trail has already gained an international reputation. It received the European Greenways Award as a best practice route in 2013. In 2014, the Vennbahn was awarded 'cycling route of the year' at the annual Dutch Cycling and Hiking fair. In 2017, the route received the 'Excellence Award' of the European Greenways Association. The German cyclist federation ADFC awarded the Vennbahn with four out of five stars on their quality assurance scheme. In its evaluation, the ADFC lauded the quality of the trail's tourism infrastructure but also highlighted the weak accessibility by public transport (Table 1). This accessibility is a widely noted problem for linear, rural rail trails (Taylor, 2015).

According to interviewees, the unique selling proposition of the Vennbahn is the fact that the route crosses the border 14 times and passes through three countries during a cycling trip of only a couple of days. The possibility to access the trail from the Netherlands was also coined during the interviews. In this sense, the borderline and its related industrial and geopolitical history functions as a direct object of tourist attention in the Vennbahn project (Gelbman \& Timothy, 2010; Timothy, 2001):

A tour operator in the Netherlands has included the Vennbahn in its program and has [made] a 'four countries tour' this way. And that is the hype. Four countries in two days. [...] What [other] country can claim this? (TAO)

Interviewees noted that the distance to the border is important in determining if this border label can be used. Even though the border label of the Vennbahn is strong in an international environment, neighbouring trails do not use the border theme in their marketing. The managers of these trails do not identify their borderland location as a marketing benefit due to slightly larger distances from the actual borderline:

For us it's too far, because Hallschlag [a borderland municipality], that's still 10 kilometers. That's too far for us. (German local tourism agency)

Despite its recent inception, the cycling route has become a strong tourism product with links to the wider tourism economy of the area. Five counting devices along the trail registered several hundred thousand individual passages in 2016 and 2017, even though the devices did not allow to correct for duplicate measurements along the itinerary. Interviewees also mentioned that the Vennbahn

Table 1

Assessment of the Vennbahn by the ADFC in its quality assurance scheme (ADFC, 2017).

\begin{tabular}{lll}
\hline Criterion & Weight & Score \\
\hline Ridability of the route & $15 \%$ & $* * *$ \\
Surface quality & $15 \%$ & $* * * *$ \\
Signposting & $15 \%$ & $* * * *$ \\
Itinerary & $5 \%$ & $* * *$ \\
Traffic intensity & $20 \%$ & $* * * * *$ \\
Quality of the touristic infrastructure & $15 \%$ & $* * * * *$ \\
Connection to train and bus & $5 \%$ & - \\
Marketing & $10 \%$ & $* * *$ \\
Overall & $100 \%$ & $* * * *$
\end{tabular}


has resulted in a large increase in value added and in total overnight stays in the direct trail surroundings. Consequently, the TAO noted that many companies try to connect their business to the Vennbahn:

This project brings lots of value added to the region. The [visitor profile] becomes younger. There are more overnight guests. That's a sign for the businesses that it works well. They see that there is a direct financial value added. [...] Three years ago, the route was officially opened, and for the last year they [ADFC certified businesses] report to us a booking increase of 20 percent. (TAO)

I know some hotels that have grown because demand has risen. New facilities have been created for cycle tourists and hikers. An example is the village Kalterherberg, where you can hardly buy a detached house today. Five years ago, you could still choose between the vacant houses. The proximity to the cycling and walking tourism routes has increased the attractiveness. (District director, Germany)

In addition, a mobile app has been developed that contains information about accommodation, gastronomy, visitor attractions, stories and the status of the route. The Vennbahn website lists accommodations that have been certified by the ADFC. Different tour packages can also be booked online. Even though the long-term stability of the route cannot be assessed due to its recent development, the combined characteristics make the Vennbahn a complex tourism product that has moved significantly beyond the instalment of route infrastructure alone.

\section{Stable financial organization and a strategic long-term vision}

The total investment costs of the Vennbahn accounted to 14.5 million Euros. Approximately 30 percent was co-financed by the EMR and Grande Region SaarLorLux INTERREG IV-a programs. The resulting 10.4 million Euros were financed from regional and municipal funds, most of which came from the Aachen regional district and the directorate-general for roads and buildings of the Wallonian regional government (EMR, 2017). The EMR sees this co-funding as a critical success factor for cross-border cooperation, especially because of the weak financial situation of many municipalities in the area. During the INTERREG IV-a EMR project period, money has been strategically pooled into only a couple of tourism projects rather than dispersed among numerous small projects. In total 20.1 million Euro was spent on five projects that dealt with slow travel, water sport, culinary tourism, a tourism information exchange platform and the Vennbahn. The Vennbahn accounted for 56 percent of the tourism budget, making it by far the largest cofunded tourism project in the area (EMR, 2017). These finances reflect the strategic vision on the foreseen leverage of the Vennbahn for broader regional cooperation in the area, as well as a calculated vision on how INTERREG funds should complement day-to-day practices:

Above all, we need to ensure that a truly lasting foundation is provided for future generations to recognize the added value of this cross-border cooperation, regardless of European funding. (Prime minister, German-speaking Community of Belgium)

I believe that these INTERREG programs should really be used only to create something you cannot do on your own and not to finance things that you could do anyway. [...] I don't need the EU to make brochures that I make every day [...] But perhaps I couldn't make projects like the Vennbahn or cross-border routes or apps by myself. There I see a real added value. (TAO)

However, the INTERREG IV-a programme period did not result in truly shared cross-border finances for marketing and additional product development. Since the initiation of the Vennbahn in 2013, several ideas were coined to establish a joint marketing and management budget but none have worked out. One proposal was to calculate the contributions of the tourism agencies in the three countries on the basis of the share of the length of the route in their territory. Another idea was to make the partners in the three countries contribute equally because of similar branding effects of the route throughout the area. Currently, the Vennbahn internet website and basic marketing material such as the route map are coordinated and mostly financed by the TAO, with the German and Luxembourgian partners paying for their use of these mediums. Trail maintenance is done by the Aachen regional district and the directorates-general for roads and buildings in Wallonia and Luxemburg. Other marketing efforts are incorporated in the individual actions of the tourism agencies. Supplementary products are also developed individually. Despite the strong tourism product, project cooperation intensity is thus still importantly shaped by INTERREG co-financing:

This cooperation always gets a new dynamic with INTERREG funds. Fortunately, when these INTERREG funds are not there, we have permanent structures that continue to work with each other but these are not as active as when there are really common funds. That is, I think, realistic to say. But it's not like we've neglected the Vennbahn. Everyone incorporates it in their own marketing, at their respective level. (TAO)

\section{Open and inclusive network of decision-making}

The decision-making process regarding tourism and regional development in East Belgium and the Eifel is remarkably similar. On both sides, the DMOs provide the interface between local actions and extra-regional (political) strategies. In Belgium, the TAO internally coordinates and externally markets the whole destination. Due to its relatively small size, the destination management has short links to local actions. Local stakeholders are included in so-called expert networks. In Germany, the ET is responsible for marketing on higher levels and the clustering of local information in booking platforms. Due to its larger size than the TAO, it depends on local tourism agencies to contact tourism entrepreneurs and community members. The regional tourist office in northern Luxemburg is more recent and more local-level in organizational structure, decision-making power and finances than the German and 
Belgian equivalents. Consequently, the TAO and the ET have strongly cooperated for a long time, with for example the establishment of the EWIV Eifel-Ardennen Marketing Organization in 2003, while institutional asymmetry has complicated information exchange with Luxembourg:

We have the EWIV just for the German-Belgian area: The East Belgium tourism association and Eifel Tourismus. In Luxemburg, there were very small regional units, which have now merged. The next level was the whole country. The entire country of course works together on a national level with Germany and Belgium. But on the level where we operate, we've never had a concrete partner. (ET)

However, this strong German-Belgian cooperation has not translated in an operational entity to manage the Vennbahn across the border. The daily management, marketing and maintenance of the Vennbahn is organized with only a basic coordination between the TAO in Belgium, the local Monschauer Land tourism agency and the Aachen regional district in Germany, and the regional tourism office in the north of Luxemburg. The TAO has a guiding role because of its scalar operations that combine extra-regional marketing and local contact to stakeholders, the central geographical position of the Vennbahn for the TAO, as well as its legitimacy as a convener. The limited power position of the Luxembourgian regional tourism office does not allow taking up such a central position. In Germany, the ET has shifted responsibility for the Vennbahn to the local level because its territory and cycling tourism offer is too large to focus predominantly on this trail:

The Vennbahn is more valuable for one than for the other. For us it's very valuable because it's the north-south axis of the region. For Germany, it's a western branch of their entire cycle network, and they cannot pay as much attention to the Vennbahn as we can because they also advertise other cycle routes. (TAO)

Establishing a joint project office is seen by most interviewees as a wanted development for the future. However, interviewees indicated that despite good basic contact there are currently no concrete solutions to deal with different opinions of stakeholders on how to proceed:

There are no fundamental problems in aligning [communication and cooperation across the border]. There are just no clear ideas how we could set up the Vennbahn permanently. (TAO)

The absence of a management office across the border means that there is no direct access of private businesses and community stakeholders to the decision-making around the trail. Stakeholder participation depends on their involvement in the individual destinations in the respective countries, which are subsequently responsible for representing them in the cross-border cooperation. In terms of marketing, ADFC certified accommodations receive additional exposure in the Vennbahn maps, brochures and internet website administered mostly by the TAO. Despite the general complexity of engaging with local stakeholders, interviewees mentioned that contact to entrepreneurs is relatively easily established in the Vennbahn due to its strategic importance and high visibility, but only directly along the trail's itinerary. The complementary nature of cross-border tourism projects to the daily efforts of the DMOs creates a feeling that the indirect representation of the businesses and communities in the Vennbahn management is satisfactory:

It's not the case that the companies are going to the joint [cross-border] meetings. This is done through the tourism organizations. But ultimately the companies also have a benefit. (ET)

\section{Institutional embeddedness of the route}

Tourism stakeholders in Germany and Belgium as well as cross-border organizations such as the EMR share the vision that the Vennbahn plays a symbolic role in the cross-border region. The Vennbahn is seen as a highlight for the whole EMR area, despite the close geographical distance of the trail to the actual borderline:

When you look at the route you immediately understand for which regions [included in the EMR territory] it's most important.

From just the geographical point of view. But every region agrees that the Vennbahn is very important and that in time every region wants to connect to the Vennbahn. (EMR manager)

Interviewees also expressed the value of the trail for 'soft' region-building in the area. The German language is shared throughout the German-Belgian borderlands and is widespread in Luxemburg, reflecting the strong political, economic and social interaction across this border for centuries. The strong connection led in the First and Second World Wars to the annexation of the Belgian borderlands by Germany. This history has led to a sensitive regional identity and historical memory that has fuelled a relatively proEuropean stance of most the population and the regional governments. Considering its explicit cross-border positioning, the Vennbahn is interpreted as a symbolic bridge to remember the past and build towards a shared future:

Regarding tourism, especially in the context of good German-Belgian cooperation, we're working to heal our wounds rather than reopen them. The Vennbahn is seen as a scar, for example. The German tourism practitioners are often quoted as such: "This is the scar that brings us together again". (TAO)

Because the cross-border cooperation between Germany and Belgium has a long history (Stoffelen \& Vanneste, 2017), and tourism is institutionalized across the border since 2003 in the EWIV Eifel-Ardennen Marketing organization, the Vennbahn should be seen as a consequence rather than an initiator of intensive cross-border information exchange. Simultaneously, the trail did contribute to 
intensifying cross-border alignment in other sectors such as healthcare and emergency services that needed to be further coordinated in case of accidents with tourists along the itinerary. Additionally, it is the only product that has directly contributed to the mainstreaming of cross-border cooperation by pulling it out of the professional environment. This visibility has led to an important local use of the trail and an increase in the practical cross-border connectivity:

The Vennbahn has become the flagship of this [cross-border] cooperation, because it's tangible not only for us and the politicians but also for the inhabitants who sometimes don't know this Grande Region or Euregio Meuse-Rhine or Eifel-Ardennen. (TAO) This cycling trail is a success story because it has shortened the [distance] between the places for the inhabitants incredibly. This is the tourism project that has brought most value to the citizens. Irrespective of its tourist appeal. (Mayor, German borderland town and director of a local tourism agency)

\section{Social and spatial dispersal of tourists and impacts}

To tap into the economic effect but also the symbolic role of the Vennbahn for the whole German-Belgian-Dutch-Luxembourgian cross-border region, other cycling routes increasingly link their marketing to the Vennbahn. Even though not all trails directly market themselves with the border theme, associating with the Vennbahn is a strategy to improve their market position and visibility. In Germany, which is densely covered by themed cycling routes, efforts take place to connect these trails in larger networks. For example, a project has developed in the Aachen regional district to create a cycling region in which such routes are cross-linked, departing from best practices such as the Vennbahn:

If you look at the RAVeL route, it starts in Aachen and goes up to Luxemburg. We're in the process of expanding corresponding cycle routes for cyclists in this area, with the goals that these premium routes are all linked to one another. (District director, Germany)

People decide to go from Aachen to Sankt Vith, and so on [to Troisvièrges]. Now they can decide to take the Vennbahn or to go to the east in direction of Oberes Kylltal and then in the direction of Trier [...] You can go by bike from the Eifel to Trier. [...] I'd say we could get a lot of clients by bike in the future. (Local tourism agency, Germany)

The TAO also tries to depart from the original itinerary to extend the length of stay of the tourists and increase the route's spatial coverage. It has developed a product called 'Vennbahn Plus', which consists of 16 maps with circular routes departing from the Vennbahn into the surrounding countryside. Plans exist to connect the route to the networked system of cycling nodes in Belgium and the Netherlands. These cross-links have resulted in a dense network with the Vennbahn as a major axis to disperse tourists around the border area (Fig. 2). The systematic connection of the Vennbahn with local, regional and international routes is seen as way to provide continuity in a context where the permanent administrative structure and future organization of the trail has not yet been found.

However, some interviewees warned for being too positive about the Vennbahn's socio-economic and spatial leverage. The advantages in terms of value added and overnight stays refers, according to interviewees, only to the direct trail surroundings. This is especially relevant for the German Eifel where the Vennbahn, as noted before, is an important tourism product but because of its peripheral geographic position has a less integrative position for the destination as a whole. Yet also the TAO, where the Vennbahn is more of a central axis due to the destination's smaller size and geographical position, remains realistic that the route cannot function as an integrative element for the whole East Belgium destination. Apart from the Vennbahn Plus, the TAO focuses on other tourism products such as hiking and mountain biking to avoid a spatial imbalance between sub-areas of the destination. They also do not think about further intensification of the trail because of its already high quality and attractiveness and the overreliance on the TAO to make this happen in the current management situation:

It will already be a challenge for us to simply keep the Vennbahn at the level where we are now. I don't think we can achieve much more. (TAO)

\section{Discussion and conclusion}

This paper established a conceptual frame of analysis (Fig. 1) to evaluate which processes determine the leverage of cycling tourism trails for mainstreaming cross-border contact, socio-economic development and 'soft' region-building. By comparing the conceptual frame to the Vennbahn, this paper found support for the basic premise of many project actions and INTERREG strategies that cross-border cycling routes could lead to numerous cross-border integration effects. Such routes can improve the prominence of borderlands and the existing cross-border cooperation practices both internationally and internally among stakeholders and communities present in the area. The European-wide attention to and popularity of cycling and trail-based tourism activities provide opportunities for cross-border cycling routes to tap into an existing demand and be included in European networks that could increase their market exposure. Additionally, the Vennbahn study shows that within the borderlands, tourism trails could have a highly symbolic role as a signifier for larger cross-border cooperation practices (Stoffelen \& Vanneste, 2018b). Cross-border cycling trails could lead to 'soft' effects such as shared mentalities and the recognition of cross-border relations among the wider public instead of only among professionals and political stakeholders. The established infrastructure and long-distance itinerary could lead to a widespread local use and thereby break down infrastructural barriers to improving cross-border social life in borderlands. Moreover, because of their linear nature (Taylor, 2015), cycling trails could provide a spatial and institutional backbone to which other tourism 
products, sectors and services could be linked. For example, the Vennbahn integrates networks of cycling routes on both sides of the border. This trail also led to the intensification of cross-border relations in other sectors such as emergency healthcare services where arrangements had been made before but where further alignment needs became tangible through the project.

The comparison of the empirical results with the literature review showed that not all elements of the explorative framework are as prominent when assessing which processes determine the leverage of cycling tourism trails for cross-border integration. While all elements from Fig. 1 proved fruitful for uncovering the functioning of the Vennbahn, the empirical results showed that two elements are the most prominent for understanding the cross-border integrative role of cycling trails. First, the paper has deepened the insights in the role of legitimate conveners for safeguarding the long-term stability of the trail and its region-building effects (Blasco et al., 2014; van der Zee et al., 2017). Adding to previous findings that bridging actors could initiate contact and overcome problems of parochialism (Blasco et al., 2014), this paper has shown that such conveners could have a crucial role in facilitating the establishment of an adaptive management to provide financial and organizational stability, tackle unforeseen cross-border cooperation complexities and establish a shared mindset between involved stakeholders. In other words, legitimate conveners are important to translate the different preconditions for trails to be successful in borderland contexts (Fig. 1) into a daily practice. The current cross-border integrating role of the Vennbahn would not be self-evident without the TAO's efforts, despite its strength as a tourism product and the good cross-border professional relations between Germany and Belgium. Additionally, cross-border tourism projects are, in most cases, supplemental rather than core actions of tourism destinations, complicating the systematic participation of local tourism and community stakeholders in these projects. Cooperation facilitators should safeguard the representation of stakeholders in the crossborder trail, either directly in a trail stakeholder management or indirectly through their participation in the internal destinations' organizational structures.

Second, the Vennbahn case showed the key role of the geographical situation of the trail and the territorial organization and scale of the involved destinations, indicated by the outline of Fig. 1. Related to this geographical situation, the institutional embeddedness of the trail also proved to be central, more so than for example the part of the conceptual framework in Fig. 1 that pointed to the direct inclusion of tourism stakeholders in open cross-border networking arrangements. This participation showed to depend upon how the project is spatially and organizationally incorporated in the destinations on both sides of the border. In the traditional sense of the concept, the institutional asymmetry between Germany and Belgium in terms of tourism is limited, which has resulted in intensive cross-border information exchange. However, the Vennbahn, because of its geographical situation directly along the border combined with the contrasting territorial coverage of the East Belgium and Eifel destinations, is more firmly embedded in East Belgium than in the Eifel despite similar administrative responsibilities and compatible multi-level governance systems (Antonson \& Jacobsen, 2014). Institutional asymmetry, in this case, refers to the skewed institutionalization of the tourism product in the destinations across the border. This situation is at the basis of the encountered difficulties to find durable and adaptive management solutions for the cycling trail and, consequently, the resilience of its cross-border region-building role. Creating a nuanced understanding of the role of tourism trails in cross-border integration, hence, requires a reconceptualization of the institutional asymmetry concept. On top of the (in)compatibility of the multi-level governance situation of tourism across the border (Stoffelen et al., 2017), the concept should also include the practical fit of tourism products in existing tourism offers and regional plans and, hence, the balance that could be achieved in positioning tourism products in the destinations on both sides of the border.

Building on a middle range research perspective that focuses on incremental knowledge creation within existing 'cross-border cooperation' paradigms (Van Houtum, 2000), these insights that nuance the current body of knowledge synthesized in Fig. 1 contribute to the extant literature by both conceptually refining and practically operationalizing the role of institutions and institutional embedding of tourism projects. Application of the presented conceptual frame in other borderland contexts would provide a starting point for further theorization of the interrelations between institutions and the spatial, political and historical borderland settings in cross-border tourism development. The conceptual frame should function as a lens to analyse context-specific issues rather than as a narrow tool for generalization. This is particularly interesting in other European settings which are overarched by the EU's policy framework, co-funding arrangements and cross-border cooperation discourse, but which entail fundamentally diverse socio-spatial and political borderland settings and cooperation histories. Tailoring the conceptual frame to non-EU settings requires additional explorative research.

Some policy recommendations can be distilled from these research findings. A key point is to think about what happens with the project after the co-funding arrangements terminate. Involved destinations should make clear agreements on finances, considering the different geographical position and importance of the trail for the destinations on both sides of the border. Finances should be made available for establishing a long-term financial plan and management entity already during the INTERREG project duration. This should also result in the appointment of a formal convener to coordinate the continuous efforts to maintain the trail, which could avoid dependency on the ad hoc willingness or sense of responsibility of one of the stakeholders during a period of lesser activity. Moreover, connecting the trails with existing cycling routes on a European level and in national networks could increase the stability of the route in absence of a cross-border management structure. These connections could also spatially disperse impacts throughout the borderlands and provide more systematic support from national and European levels than only project funding. Finally, INTERREG projects should self-evaluate using continuous qualitative reflections on cross-border cooperation, management and participation experiences of stakeholders rather than solely ex-post quantitative outcome indicators (Vanclay, 2015). However, considering the struggle to establish of some of these arrangements even in an integrated borderland (Timothy, 2001) with a best practice route as the Vennbahn, it can be expected that there is a large unfulfilled potential of cross-border tourism trails in terms of contributing to cross-border communication and social cohesion in many European borderlands. 


\section{Acknowledgements}

This work was partly supported by the Research Foundation - Flanders (FWO). The author wishes to thank Dominique Vanneste for the discussions in earlier phases of the research.

\section{References}

ADFC. (2017). ADFC-Qualitätsradrouten mit 4 Sternen. Retrieved from September 20, 2017 https://www.adfc.de/deutschland/adfc-qualitaetsradrouten/adfc qualitaetsradrouten-mit-4-sternen.

Amin, A., \& Thrift, N. (1994). Living in the global. In A. Amin, \& N. Thrift (Eds.). Globalization, institutions, and regional development in Europe (pp. 1-22). Oxford: Oxford University Press.

Antonson, H., \& Jacobsen, J. K. S. (2014). Tourism development strategy or just brown signage? Comparing road administration policies and designation procedures for official tourism routes in two Scandinavian countries. Land Use Policy, 36, 342-350. https://doi.org/10.1016/j.landusepol.2013.09.003.

Blasco, D., Guia, J., \& Prats, L. (2014). Emergence of governance in cross-border destinations. Annals of Tourism Research, 49, 159-173. https://doi.org/10.1016/j. annals.2014.09.002.

Briedenhann, J., \& Wickens, E. (2004). Tourism routes as a tool for the economic development of rural areas - vibrant hope or impossible dream? Tourism Management, 25(1), 71-79. https://doi.org/10.1016/S0261-5177(03)00063-3.

Church, A., \& Reid, P. (1999). Cross-border co-operation, institutionalization and political space across the English Channel. Regional Studies, 33(7), 643-655. https:// doi.org/10.1080/00343409950078684.

Deppisch, S. (2012). Governance processes in Euregios. Evidence from six cases across the Austrian-German border. Planning Practice and Research, 27(3), 315-332. https://doi.org/10.1080/02697459.2012.670937.

ECF. (2017). What is EuroVelo? Retrieved from September 1, 2017 http://www.eurovelo.org/.

EMR. (2017). List of beneficiaries INTERREG IV-A EMR.

Gelbman, A., \& Timothy, D. J. (2010). From hostile boundaries to tourist attractions. Current Issues in Tourism, 13(3), 239-259. https://doi.org/10.1080/ 13683500903033278.

Hayes, D., \& Macleod, N. (2008). Putting down routes: An examination of local government cultural policy shaping the development of heritage trails. Managing Leisure, 13, 57-73.

Ilbery, B., \& Saxena, G. (2011). Integrated rural tourism in the English-Welsh cross-border region: An analysis of strategic, administrative and personal challenges. Regional Studies, 45(8), 1139-1155. https://doi.org/10.1080/00343404.2010.486785.

Ioannides, D., Nielsen, P.A., \& Billing, P. (2006). Transboundary collaboration in tourism: The case of the Bothnian Arc. Tourism Geographies, 8(2), 122-142. https:// doi.org/10.1080/14616680600585380.

Klatt, M., \& Herrmann, H. (2011). Half empty or half full ? Over 30 years of regional cross-border cooperation within the EU: Experiences at the Dutch-German and Danish-German border. Journal of Borderlands Studies, 26(1), 65-87. https://doi.org/10.1080/08865655.2011.590289.

Lumsdon, L. (2000). Transport and tourism: Cycle tourism - a model for sustainable development? Journal of Sustainable Tourism, 8(5), 361-377. https://doi.org/10. $1080 / 09669580008667373$.

MacLeod, N. (2017). The role of trails in the creation of tourist space. Journal of Heritage Tourism, 12(5), 423-430. https://doi.org/10.1080/1743873X.2016.1242590.

Martin, A., \& McBoyle, G. (2006). Scotland's Malt Whisky Trail: Management issues in a public-private tourism marketing partnership. International Journal of Wine Marketing, 18(2), 98-111. https://doi.org/10.1108/09547540610681086.

Martínez, O. J. (1994). Border people: Life and society in the U.S. - Mexico borderlands. Tucson: University of Arizona Press.

Mason, R., \& O'Mahony, B. (2007). On the trail of food and wine: The tourist search for meaningful experience. Annals of Leisure Research, 10(3-4), 391-412. https:// doi.org/10.1080/11745398.2007.9686773.

Meschik, M. (2012). Sustainable cycle tourism along the Danube cycle route in Austria. Tourism Planning and Development, 9(1), 41-56. https://doi.org/10.1080/ 21568316.2012.653478.

Meyer, D. (2004). Tourism routes and gateways: Key issues for the development of tourism routes and gateways and their potential for pro-poor Tourism. London: Overseas Development Institute.

Ministerium der Deutschsprachigen Gemeinschaft. (n.d.). Vennbahn-Route. Eupen.

Morrow, S. (2005). Continuity and change: The planning and management of long distance walking routes in Scotland. Managing Leisure, 10(4), 237-250. https://doi. org/10.1080/13606710500348094.

Plummer, R., Telfer, D., \& Hashimoto, A. (2006). The rise and fall of the Waterloo-Wellington Ale Trail: A study of collaboration within the tourism industry. Current Issues in Tourism, 9(3), 191-205.

Prokkola, E.-K. (2008). Resources and barriers in tourism development: Cross-border cooperation, regionalization and destination building at the Finnish-Swedish border. Fennia, 186(1), 31-46.

Prokkola, E.-K. (2010). Borders in tourism: The transformation of the Swedish-Finnish border landscape. Current Issues in Tourism, 13(3), 223-238. https://doi.org/10. 1080/13683500902990528.

Quinlan Cutler, S., Carmichael, B., \& Doherty, S. (2014). The inca trail experience: Does the journey matter? Annals of Tourism Research, 45, 152-166. https://doi.org/ 10.1016/j.annals.2013.12.016.

Ritchie, B. W., \& Hall, C. M. (1999). Bicycle tourism and regional development: A New Zealand case study. Anatolia, 10(2), 89-112. https://doi.org/10.1080/ 13032917.1999 .9686974$.

Rogerson, C. M. (2007). Tourism routes as vehicles for local economic development in South Africa: The example of the Magaliesberg Meander. Urban Forum, 18(2), 49-68. https://doi.org/10.1007/s12132-007-9006-5.

Ryan, R. L., Fábos, J. G., \& Allan, J. J. (2006). Understanding opportunities and challenges for collaborative greenway planning in New England. Landscape and Urban Planning, 76(1-4), 172-191. https://doi.org/10.1016/j.landurbplan.2004.09.031.

Saxena, G., \& Ilbery, B. (2008). Integrated rural tourism: A border case study. Annals of Tourism Research, 35(1), 233-254. https://doi.org/10.1016/j.annals.2007.07. 010.

Snowball, J. D., \& Courtney, S. (2010). Cultural heritage routes in South Africa: Effective tools for heritage conservation and local economic development? Development Southern Africa, 27(4), 563-576. https://doi.org/10.1080/0376835X.2010.508589.

Sofield, T. H. B. (2006). Border tourism and border communities: An overview. Tourism Geographies, 8(2), 102-121. https://doi.org/10.1080/14616680600585489.

Spierings, B., \& van der Velde, M. (2013). Cross-border differences and unfamiliarity: Shopping mobility in the Dutch-German Rhine-Waal Euroregion. European Planning Studies, 21(1), 5-23. https://doi.org/10.1080/09654313.2012.716236.

Stoffelen, A. (2018). Disentangling the tourism sector's fragmentation: A hands-on coding/post-coding guide for interview and policy document analysis in tourism. Current Issues in Tourism, 1-14. https://doi.org/10.1080/13683500.2018.1441268.

Stoffelen, A., Ioannides, D., \& Vanneste, D. (2017). Obstacles to achieving cross-border tourism governance: A multi-scalar approach focusing on the German-Czech borderlands. Annals of Tourism Research, 64, 126-138. https://doi.org/10.1016/j.annals.2017.03.003.

Stoffelen, A., \& Vanneste, D. (2016). Institutional (dis)integration and regional development implications of whisky tourism in Speyside, Scotland. Scandinavian Journal of Hospitality and Tourism, 16(1), 42-60. https://doi.org/10.1080/15022250.2015.1062416.

Stoffelen, A., \& Vanneste, D. (2017). Tourism and cross-border regional development: Insights in European contexts. European Planning Studies, 25(6), 1013-1033. https://doi.org/10.1080/09654313.2017.1291585. 
Stoffelen, A., \& Vanneste, D. (2018a). Commodification of contested borderscapes for tourism development: Viability, community representation and equity of relic Iron Curtain and Sudetenland heritage tourism landscapes. In A. Paasi, E.-. K. Prokkola, J. Saarinen, \& K. Zimmerbauer (Eds.). Borderless worlds for whom? Ethics, moralities and mobilities (pp. 139-153). London: Routledge (in press).

Stoffelen, A., \& Vanneste, D. (2018b). The role of history and identity discourses in cross-border tourism destination development: A Vogtland case study. Journal of Destination Marketing and Management, 204-213. https://doi.org/10.1016/j.jdmm.2017.04.003.

Taylor, P. (2015). What factors make rail trails successful as tourism attractions? Developing a conceptual framework from relevant literature. Journal of Outdoor Recreation and Tourism, 12, 89-98. https://doi.org/10.1016/j.jort.2015.11.005.

Timothy, D. J. (1995). Political boundaries and tourism: Borders as tourist attractions. Tourism Management, 16(7), 525-532. https://doi.org/10.1016/0261-5177(95) 00070-5.

Timothy, D. J. (1999). Cross-border partnership in tourism resource management: International parks along the US-Canada Border. Journal of Sustainable Tourism, $7(3-4), 182-205$.

Timothy, D. J. (2001). Tourism and political boundaries. London: Routledge.

Timothy, D. J., \& Boyd, S. W. (2015). Tourism and trails: Cultural, ecological and management issues. Bristol: Channel View Publications.

Timothy, D. J., Saarinen, J., \& Viken, A. (2016). Editorial: Tourism issues and international borders in the Nordic Region. Scandinavian Journal of Hospitality and Tourism, 16(Sup. 1), 1-13. https://doi.org/10.1080/15022250.2016.1244504.

van der Zee, E., Gerrets, A. M., \& Vanneste, D. (2017). Complexity in the governance of tourism networks: Balancing between external pressure and internal expectations. Journal of Destination Marketing and Management, 6(4), 296-308. https://doi.org/10.1016/j.jdmm.2017.07.003.

Van Houtum, H. (2000). An overview of European geographical research on borders and border regions. Journal of Borderlands Studies, XV(1), 57-83.

Vanclay, F. (2015). The potential application of qualitative evaluation methods in European regional development: Reflections on the use of performance story reporting in Australian natural resource management. Regional Studies, 49(8), 1326-1339. https://doi.org/10.1080/00343404.2013.837998.

Vennbahn. (2017). The project. Retrieved September from 20, 2017 http://www.vennbahn.eu/en/the-project/.

Arie Stoffelen (h.j.w.stoffelen@rug.nl) is an assistant professor at the University of Groningen (Netherlands). He is also coordinator of the Master Cultural Geography and the Tourism Geography and Planning track at that university. His research interests centre on tourism-induced regional development and tourism landscape creation, including geotourism development. He studies the role of tourism in cross-border cooperation processes, mainly in European contexts, as well as tourism livelihood creations in the Global South. 